\title{
Carbon Dioxide Emissions from Thermal Power Plants in Cameroon: A Case Study in Dibamba Power Development Company
}

\author{
Jean Gaston Tamba ${ }^{1}$, Francis Djanna Koffi ${ }^{1}$, Louis Monkam ${ }^{1}$, Simon Koumi Ngoh ${ }^{1}$, \\ Serge Nyobe Biobiongono ${ }^{2}$ \\ ${ }^{1}$ Department of Thermal and Energy Engineering, University Institute of Technology, University of Douala, Douala, Cameroon; \\ ${ }^{2}$ Dibamba Power Development Company, Douala, Cameroon. \\ Email: *tambajeangaston@yahoo.fr
}

Received September $28^{\text {th }}, 2013$; revised October $25^{\text {th }}, 2013$; accepted November $1^{\text {st }}, 2013$

Copyright (C) 2013 Jean Gaston Tamba et al. This is an open access article distributed under the Creative Commons Attribution License, which permits unrestricted use, distribution, and reproduction in any medium, provided the original work is properly cited.

\begin{abstract}
This paper centres on the estimation of carbon dioxide emissions in a Cameroon thermal power plant called Dibamba Power Development Company, in such a way that they can be included as part of Cameroon energy sector inventory or used by the Dibamba Power Development Company to monitor its policy and technology improvements for mitigating climate change. We have estimated the emissions using national emission factors for the consumption of liquid fossil fuels and simulated a mitigation of these emissions till 2018 using alternative fossil fuels and carbon neutral model. The results show that energy demand and carbon dioxide emissions in 2012 are estimated to be $48.964 \mathrm{ktoe}$ and $164.39 \mathrm{kt}$ $\mathrm{CO}_{2}$ respectively. National emission factors for electricity generation are estimated to be $660.63 \mathrm{~g} / \mathrm{kWh}$. From 2012 to 2018, the thermal power plant will emit into the atmosphere $1298.42 \mathrm{kt} \mathrm{CO}_{2}$. These results also show that the use of alternative fuels will reduce $59.22 \mathrm{kt} \mathrm{CO}_{2}$ per year for the same period while the use of the carbon neutral model will reduce a total amount of $8.08 \mathrm{kt} \mathrm{CO}_{2}$. Finally, the total quantity of $\mathrm{CO}_{2}$ emission reduced for the period 2012 to 2018 will be $489.91 \mathrm{kt} \mathrm{CO}$.
\end{abstract}

Keywords: Assessment; Carbon Dioxide Emissions; DPDC; Cameroon

\section{Introduction}

The increase of greenhouse gases (GHG) emissions is an important and most concerned issue. Human activities are currently based on high consumption of fuels, and are actually the major cause of GHG emissions, which can undoubtedly be related with climatic changes [1]. There are six greenhouse gasses (GHGs) with their respective radiative forcing and global warming potential (GWP) [2]. However, carbon dioxide $\left(\mathrm{CO}_{2}\right)$ emissions are the most important of the GHGs that are increasing in atmospheric concentration because of human activities [3].

Transportation, industrial and electricity production (with fossil fuels combustion) are the main sectors identified to contribute to the emission of $\mathrm{CO}_{2}$ in Cameroon. The electric power installed in Cameroon for the production of electricity is $1593 \mathrm{MW}$ and 18 percent of this

${ }^{*}$ Corresponding author. power is occupied by thermal power plants [4]. Currently, in Cameroon, the issue of $\mathrm{CO}_{2}$ emissions in thermal power plants is the focus of environmental policies of the country. Note that Cameroon has a fleet of electricity generation plants (thermal power) with a value of 285 MW which operates using fossil liquid fuels [4]. Among the thermal power plants that have this park, the Dibamba Power Development Company (DPDC) is the largest with $88 \mathrm{MW}$ of installed power.

This paper estimates $\mathrm{CO}_{2}$ emissions in DPDC, comprising national emission factors for fossil liquid fuels consumption $[5,6] . \mathrm{CO}_{2}$ emissions considered in this study are from the fossil liquid fuels consumption needed for electricity production. It is the emission from stationary combustion (thermoelectric power station) and mobile combustion (vehicles) of the DPDC. The paper also calculates the national emission factors for electricity generation (kilogram $\mathrm{CO}_{2}$ per kilo watt hour) in 2012. In 
addition, the paper shows a perspective mitigation of $\mathrm{CO}_{2}$ emissions of DPDC from 2015 using the alternative fossil fuels and the carbon neutral model.

The objectives of this paper are: 1) to show how the $\mathrm{CO}_{2}$ emissions of thermal power plants can be estimated; 2) to improve on the second National Communication of GHG emissions inventories of Cameroon to the United Nations Framework Convention on Climate Change (UNFCCC); 3) to permit future policies to deploy new technologies with low carbon emission and consequently reduce $\mathrm{CO}_{2}$ emissions for Cameroon's thermal power plants sector; 4) to permit DPDC to calculate $\mathrm{CO}_{2}$ emissions using national emission factors.

The remainder of this paper is organised as follows: we present an overview of DPDC in the next section. Section 3 describes an overview of energy demand. Section 4 presents an overview of the proposed methodology. The results are reported in Section 5 and the last section concludes the study.

\section{Overview of DPDC}

DPDC (Figure 1) is a mixed company specialised in electric energy generation. It was created in 2011 and it only uses power plants. DPDC is a subsidiary of AESSonel (Apply Energizing Services-National Society of electricity). It covers an area of 10 hectare (ha) with one and 5 ha of lawn and grass respectively. In 2015, DPDC will replace the 5 ha of grass with complex ecology. The complex ecology is made of local trees and bushes. AES-Sonel is the major shareholder with $56 \%$ stake and the state of Cameroon with 44\% [7]. DPDC is located in the Littoral region of Cameroon, latitude $3^{\circ} 59^{\prime}$ North and $9^{\circ} 48^{\prime}$ East. It has eight identical thermoelectric power stations brand Wartsila, an installed capacity of $11 \mathrm{MW}$ each [8]. Hence, DPDC is the largest thermal power plant (88 MW) consuming fossil liquid fuels [4]. The thermoelectric power stations run only on heavy fuel oil (HFO), while vehicles of the power plant run on gasoline and diesel.

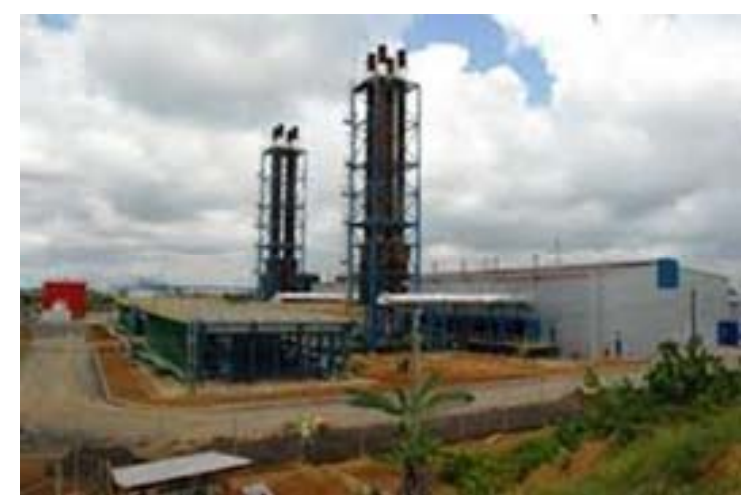

Figure 1. DPDC.
The running time of DPDC or Dibamba power plants is not constant (Figure 2). On the AES-Sonel request, Dibamba power plants come to reinforce the hydroelectric plants to offset the energetic deficit. Figure 2 shows that the working hour of thermoelectric power station of DPDC is low (inferior to 200 hours) from June to November. This period corresponds to the Cameroon rainy season [9]. March 2012 is the month during which the power plant has turned more. Service hours represent the working real time of thermal generator and period hours the number of real hours in the month.

\section{Overview of Energy Demand}

\subsection{Electricity Generation}

On the request of AES-Sonel, DPDC sends $86 \mathrm{MW}$ of electric power to the national grid [7]. However, 2 MW of electric power are used to supply the auxiliary power plants. The monthly electricity generation is presented in Figure 3. Gross generation is the total electricity generation (national grid and auxiliary power plants) in DPDC. In 2012, DPDC generated 21.393 kilotons oil equivalent (ktoe) $(248,758 \mathrm{MWh})$ of electricity. From June to No-

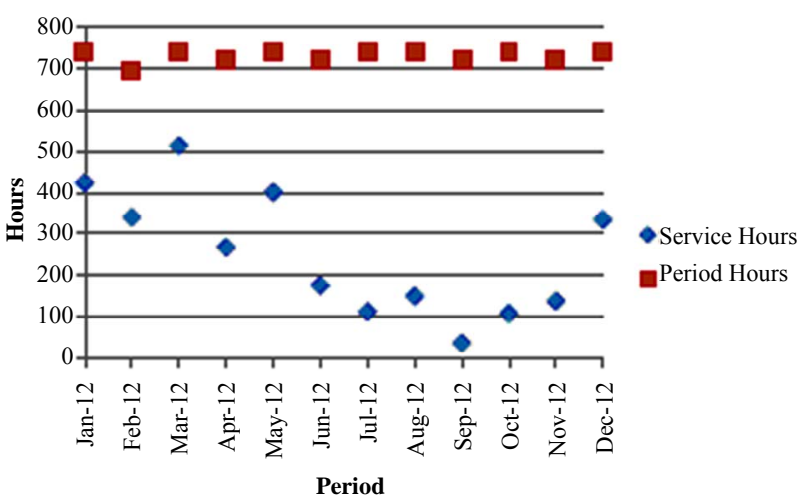

Figure 2. Service hours of Dibamba power plants from January to December 2012.

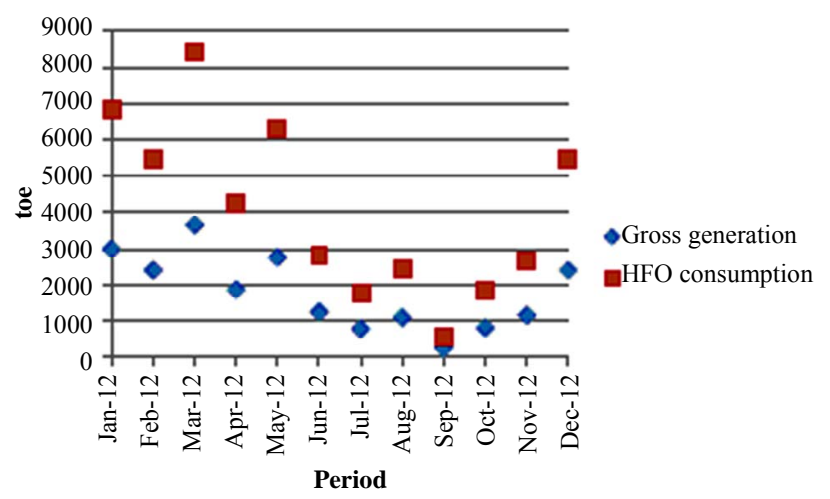

Figure 3. Electricity generation and HFO consumption from January to December 2012. 
vember, the electricity generation is weaker than the other months. Hence, during this period AES-Sonel solicits more hydropower plants.

\subsection{HFO Consumption}

A thermal power plant needs fuel to generate electrical energy. Thus, DPDC uses HFO to generate its electricity. HFO consumption to produce electricity is responsible for $\mathrm{GHG}$ emissions in general and $\mathrm{CO}_{2}$ in particular. As for the case of electricity generation, Figure 3 shows the monthly evolution of HFO consumption in 2012. We also note that HFO consumption is lower from June to November. So, DPDC used $48.939 \mathrm{k} \cdot$ toe $\left(53,774 \mathrm{~m}^{3}\right)$ of HFO to generate electricity in 2012.

\subsection{Gasoline and Diesel Consumption}

Gasoline and diesel are used in vehicles. DPDC has six (06) vehicles, with four (04) vehicles using diesel and two (02) gasoline. The vehicles contribute to electricity generation through transport of equipment and workers of DPDC. Unlike Figures 2 and 3, Figure 4 clearly shows that fossil liquid fuels (gasoline and diesel) consumption is not influenced by climatic seasons. This consumption can be influenced by the duration of maintenance of the thermoelectric power station [10]. Diesel consumption is more important than gasoline in 2012, about 21.114 tons oil equivalent (toe) $\left(23.666 \mathrm{~m}^{3}\right)$ for diesel consumption against 4.489 toe $\left(5.462 \mathrm{~m}^{3}\right)$ for gasoline.

\subsection{Future Demand of Fossil Fuels}

Figure 5 shows the future demand of fossil fuels in DPDC. This demand corresponds to the AES-Scenario. This stipulates that fossil fuels demand in thermal power plants increases by $4 \%$ from 2012 to 2018 in average [7]. Knowing that energy demand increases by about $8 \%$ each year in Cameroon [4], 4\% increase of fossil fuels will contribute to satisfy energy demand and consequen-

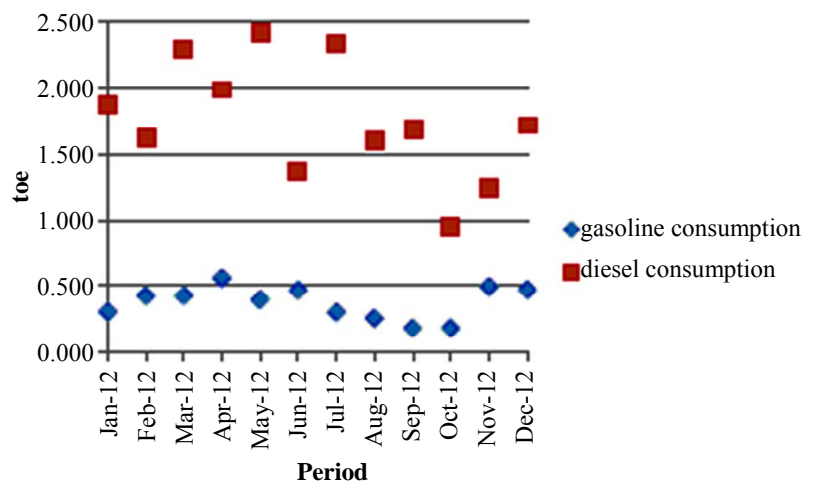

Figure 4. Gasoline and diesel consumption by vehicles from January to December 2012.

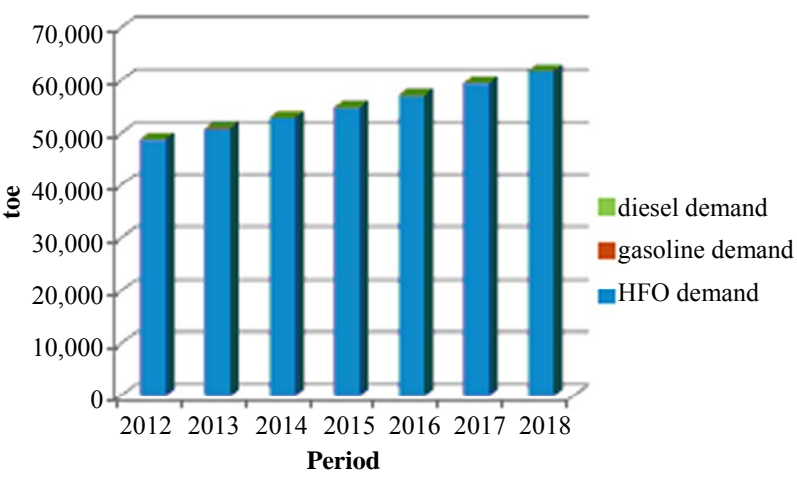

Figure 5. Fossil fuels demand in AES-scenario.

tly increase the amount of $\mathrm{CO}_{2}$ in the atmosphere. Thus, fossil fuels demand will increase by $12.991 \mathrm{k} \cdot$ toe (about $26.53 \%)$ from $2012(48.964 \mathrm{k} \cdot$ toe $)$ to $2018(61.955 \cdot \mathrm{k} \cdot$ toe $)$.

\section{Methodology}

In general, for each source sector or category, $\mathrm{CO}_{2}$ emissions are calculated when the quantity of fuel consumed at the national level of detail is multiplied by a specific national emission factor [1,3,5,6,11-13]. $\mathrm{CO}_{2}$ emissions in DPDC are estimated as follows:

$$
E_{t}=\sum_{i}\left(F C_{i, t} \cdot D_{i} \cdot L H V_{i} \cdot E F_{i, C O 2}\right)
$$

where the subscript $i$ represents the fuel type; $E F_{i, C O 2}$ the national emission factor of $\mathrm{CO}_{2}$ of the $i$ th fuel; $L H V_{i}$ the national lower heating value on fuel type $i$ and $D_{i}$ is the national density at $15^{\circ} \mathrm{C}$ on fuel type $i$ [5]. $F C_{i, t}$ is fossil liquid fuels consumed on fuel type in period $t$. Fuel consumption is marked by a meter and/or estimated by Equation (2) for thermoelectric power stations, while it is estimated by Equation (3) for vehicles [14].

$$
\begin{gathered}
F C_{t}=(\text { HFO sales to DPDC })_{t} \\
F C_{t}=\left(\sum_{i} V_{i, t} \cdot V K T_{i, t} \cdot V O R_{t}\right) A F_{t}
\end{gathered}
$$

where $A F_{t}$ is the average number of kilometers travelled for a vehicle per litre of fuel consumed each period $t$ and $V O R_{t}$ is the vehicle occupancy rate for each period $t . V K T_{i, t}$ represents the average annual vehicle-kilometer travelled by a vehicle on fuel type $i$ in period $t$ and $V_{i, t}$ the number of vehicles on fuel type $i$ in period $t$.

After $\mathrm{CO}_{2}$ emissions calculation attributable to the electricity generation in the DPDC, we calculate national emission factors for electricity generation as follows:

$$
E F_{t}=\frac{E_{t}}{E G_{t}}
$$


where $t$ represents the period, $E$ total $\mathrm{CO}_{2}$ emissions and EG total electricity generation in DPDC.

DPDC plans to move to alternative fossil fuel as from 2015 (DPDC-Scenario). Applying the AES-Scenario, DPDC will change HFO demand to natural gas inorder to generate electricity from 2015 to 2018, which will reduce the amount of $\mathrm{CO}_{2}$ emitted by DPDC into the atmosphere. The calculation mechanism of $\mathrm{CO}_{2}$ emissions from the natural gas consumption to generate electricity is as follows: we convert HFO demand to natural gas demand from 2015 to 2018 [15,16] and then we apply Equation (1). Thus, $\mathrm{CO}_{2}$ emissions that will be reduced by DPDC are estimated by Equation (5):

$$
E_{R, t}=E_{t}-E_{t}^{\prime}
$$

where $E_{R}$ represents $\mathrm{CO}_{2}$ emissions reduced; $E$ the total $\mathrm{CO}_{2}$ emissions (in the AES-Scenario), $E^{\prime}$ the total $\mathrm{CO}_{2}$ emissions (in the DPDC-Scenario) and $t$ is from 2012 to 2018.

A regional carbon neutral model was built in this research to assess total $\mathrm{CO}_{2}$ absorption by plants in DPDC. The carbon neutral model structure is shown in [17]. The total $\mathrm{CO}_{2}$ fixation volume calculation formula is displayed in Equations (6)-(8) [17,18].

$$
\begin{gathered}
A b s_{\mathrm{CO} 2}=\left(\sum_{i} G_{i} \cdot A_{i}\right) a \\
\alpha=0.8+0.5 \cdot r a \\
r a=\left(20 \sum_{i=1}^{n^{\prime}} N t_{i}^{\prime}+\sum_{i=1}^{n b^{\prime}} N b_{i}^{\prime}\right) /\left(20 \sum_{i=1}^{n} N t_{i}+\sum_{i=1}^{n b} N b_{i}\right)
\end{gathered}
$$

where the $A b s_{\mathrm{CO} 2}$ is the is the total $\mathrm{CO}_{2}$ absorption volume of green areas; $A_{i}$ is the green area and $G_{i}$ is the $\mathrm{CO}_{2}$ fixation volume in unit area for the plant. $n$ and $N t$ are the kinds and numbers of tree respectively. $n^{\prime}$ and $N t^{\prime}$ are the kinds and numbers of the original trees in the country respectively. $n b$ and $N b$ are the kinds and numbers of bushes respectively. $n b^{\prime}$ and $N b^{\prime}$ are the kinds and numbers of original bushes in the country respectively. In this study, all plants used are local. Thus, Equation (8) simplifies and is rewritten as Equation (9).

$$
r a=1
$$

\section{Results and Discussion}

\section{1. $\mathrm{CO}_{2}$ Emissions}

Figure 6 presents the results of $\mathrm{CO}_{2}$ emissions in DPDC. $\mathrm{CO}_{2}$ emissions are in the range of $1.945-28.399$ kilotons $\mathrm{CO}_{2}\left(\mathrm{kt} \mathrm{CO}_{2}\right)$ for September and March respectively. We note that $\mathrm{CO}_{2}$ emissions are lower (less to $10 \mathrm{kt} \mathrm{CO}_{2}$ ) from June to November. These low $\mathrm{CO}_{2}$ emissions are clearly justified by the service hours (Figure 2), energy consumption (Figure 3) and Equation (1). So we con- clude that electricity generation is less solicited during this period. In 2012, DPDC rejects in the atmosphere about 164.393 kt $\mathrm{CO}_{2}, 13.699$ kt $\mathrm{CO}_{2}$ per month averagely. National emission factor (Figure 7) is in the range of $653.48-667.87 \mathrm{~g} / \mathrm{kWh}$ for February and March respectively.

Contrary to Figure 6, Figure 7 clearly shows that national emission factor of $\mathrm{CO}_{2}$ is not influenced by climatic seasons. In average, the national emission factor of $\mathrm{CO}_{2}$ is about $660.63 \mathrm{~g} / \mathrm{kWh}$ in 2012 . When we analyze emissions under AES-Scenario, the results show that $\mathrm{CO}_{2}$ emissions in atmosphere are in the range $164.39-$ $208.01 \mathrm{kt} \mathrm{CO}_{2}$ from 2012 to 2018 respectively, while DPDC-Scenario shows that $\mathrm{CO}_{2}$ emissions are in the range 164.39 - $145.26 \mathrm{kt} \mathrm{CO}_{2}$ from 2012 to 2018 respectively (Figure 8). Note that from 2012 to 2018, the AESScenario will emit in the atmosphere a total quantity of $1298.42 \mathrm{kt} \mathrm{CO}_{2}$ while if the DPDC-Scenario is applied, the total quantity emitted will be $906.74 \mathrm{kt} \mathrm{CO}_{2}$.

\subsection{Mitigation of $\mathrm{CO}_{2}$ Emissions}

Figure 8 shows the amount of $\mathrm{CO}_{2}$ emissions that will be reduced by alternating the HFO to natural gas by DPDC. The application of DPDC-Scenario will reduce $\mathrm{CO}_{2}$

घFO $\mathrm{CO}_{2}$ emissions $\square$ gasoline $\mathrm{CO}_{2}$ emissions $\llbracket$ diesel $\mathrm{CO} 2$ emissions

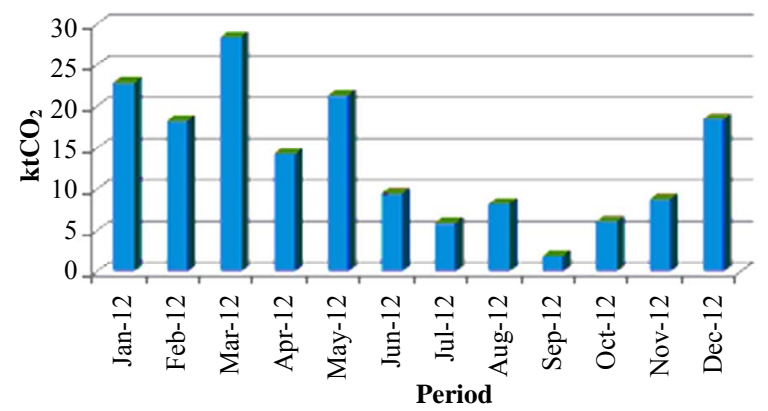

Figure 6. $\mathrm{CO}_{2}$ emissions in DPDC from January to December 2012.

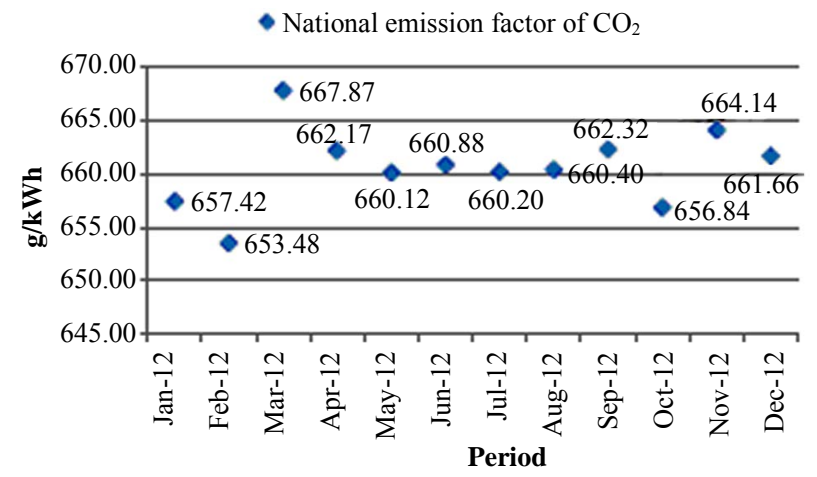

Figure 7. National emission factor for electricity generation (g/kWh) of $\mathrm{CO}_{2}$ from January to December 2012. 
emissions in the atmosphere by 55.78, 58.02, 60.34 and $62.75 \mathrm{kt} \mathrm{CO}_{2}$ in 2015, 2016, 2017 and 2018 respectively. Thus, $59.22 \mathrm{kt} \mathrm{CO}_{2}$ in average will be reduced per year from 2012 to 2018 by DPDC.

Figure 9 presents the total mitigation of $\mathrm{CO}_{2}$ emissions. Mitigation1 represents $\mathrm{CO}_{2}$ emissions reduction with alternative fossil fuel, Mitigation $2 \mathrm{CO}_{2}$ emissions reduction with plant absorption and Mitigation 3 total $\mathrm{CO}_{2}$ emissions reduction. $\mathrm{CO}_{2}$ absorption volumes of green areas are in the range of $0.04-1.99 \mathrm{kt} \mathrm{CO}_{2}$ for 2012 and 2018 respectively. So plants will absorb $8.08 \mathrm{kt}$ $\mathrm{CO}_{2}$ from 2012 to 2018. Finally, applying DPDC-Scenario and $\mathrm{CO}_{2}$ absorption by plants (complex ecology and lawn), DPDC will reduce their $\mathrm{CO}_{2}$ emissions of $64.74 \mathrm{kt} \mathrm{CO}_{2}$ in 2018. Finally, the total amount of $\mathrm{CO}_{2}$ reduced for the period 2012 to 2018 will be of the order of $489.91 \mathrm{kt}$.

\subsection{Policy Implication}

Although it is a Non-Annex 1 party, Cameroon became a member of the United Nations Framework Convention on Climate Change in 1994. Thus, it is committed with the international community to help stabilize concentrations of greenhouse gases (GHGs) in the atmosphere to an extent that would prevent dangerous interference of human activities with the climate system. Given the

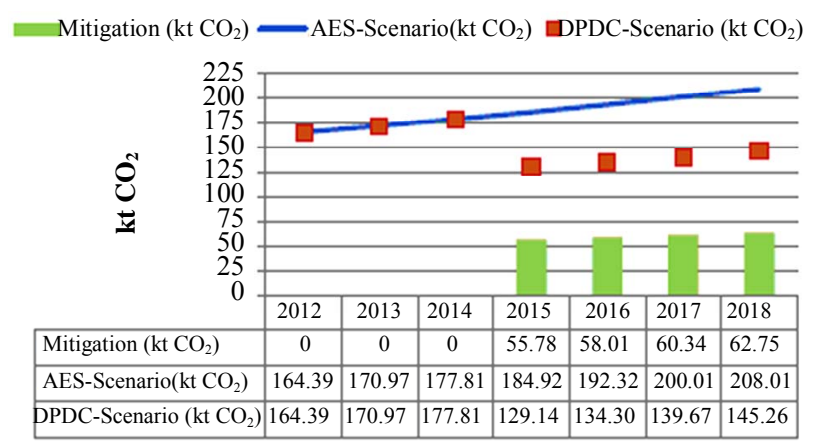

Figure 8. Mitigation of $\mathrm{CO}_{2}$ emissions with alternative fossil fuel.

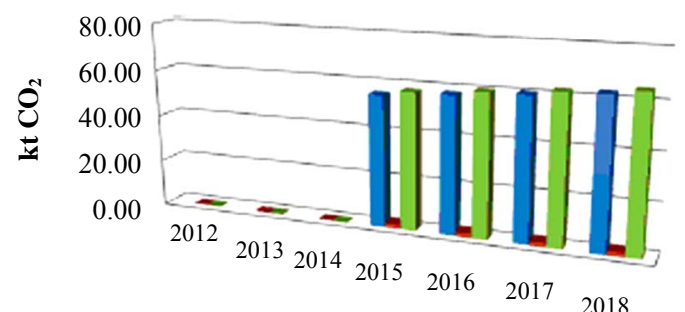

\begin{tabular}{|l|l|l|l|l|l|l|c|}
\cline { 2 - 8 } \multicolumn{1}{c|}{} & 2012 & 2013 & 2014 & 2015 & 2016 & 2017 & 2018 \\
\hline Mitigation1 $\left(\mathrm{kt} \mathrm{CO}_{2}\right)$ & & & & 55.78 & 58.01 & 60.34 & 62.75 \\
\hline Mitigation1 $\left(\mathrm{kt} \mathrm{CO}_{2}\right)$ & 0.04 & 0.04 & 0.04 & 1.99 & 1.99 & 1.99 & 1.99 \\
\hline Mitigation1 $\left(\mathrm{kt} \mathrm{CO}_{2}\right)$ & 0.04 & 0.04 & 0.04 & 57.77 & 60.00 & 62.32 & 64.74 \\
\hline
\end{tabular}

Figure 9. Total mitigation of $\mathrm{CO}_{2}$ emissions. amount of $\mathrm{CO}_{2}$ emitted into the atmosphere by the DPDC, mitigation policies must be taken for all thermal power plants, preferably by considering the realities of Cameroon. As a Non-Annex 1 party, Cameroon's government has the right to insure favorable conditions to its development, which inevitably requires the heavily investment in the promotion of carbon reduction. Taxes on carbon are not an important point for the Cameroon ministry of environment. For Cameroon is considered as a NonAnnex 1 party and its emissions are by far lower than that of industrialized countries as well as the production of electricity by thermal power plants in all other sectors.

Although there are several possible strategies to reduce the amount of $\mathrm{CO}_{2}$ emitted from fossil fuel power plants, Cameroon government suggests potential approaches that include increasing plant efficiency, employing fuel balancing or fuel switching and rapid recovery of plants by complex ecology plants, for all thermal power plants in the country. The Cameroon ministry of environment suggests to AES-Sonel concerning thermal power plants to put in place an environmental policy in these power plants. This policy includes planting one tree per employee for each AES-Sonel power plant per year. Thus, the fixation volume by plants will increase and will thus reduce the amount of $\mathrm{CO}_{2}$ emissions.

\section{Conclusions}

Energy demand and $\mathrm{CO}_{2}$ emissions by DPDC in 2012 are estimated to be $48.964 \mathrm{k} \cdot$ toe and $164.39 \mathrm{kt} \mathrm{CO}_{2}$ respectively. From 2012 to 2018, applying AES-Scenario will emit into the atmosphere $1298.42 \mathrm{kt} \mathrm{CO}_{2}$. On the other hand, applying DPDC-Scenario and carbon neutral model by plants will reduce $\mathrm{CO}_{2}$ emissions by $489.91 \mathrm{kt}$ $\mathrm{CO}_{2}$ for the same period. With the above discussions, it can be concluded that:

1) The study shows how the $\mathrm{CO}_{2}$ emissions of thermal power plants are estimated.

2) The study also permits DPDC to calculate $\mathrm{CO}_{2}$ emissions using national emission factors.

3) The Cameroon government can use this study to improve on the second National Communication of GHG emissions inventories to the United Nations Framework Convention on Climate Change.

4) Future environmental policies in Cameroon should deploy new technologies, alternating fuels with liquid fossil fuels and increase green areas around power plants, and consequently reduce $\mathrm{CO}_{2}$ emissions for Cameroon's thermal power plants sector.

\section{REFERENCES}

[1] J. Gomes, J. Nascimento and H. Rodrigues, "Estimating Local Greenhouse Gas Emissions-A Case Study on a 
Portuguese Municipality," International Journal of Greenhouse Gas Control, Vol. 2, No. 1, 2008, pp. 130-135. http://dx.doi.org/10.1016/S1750-5836(07)00098-9

[2] IPCC, "Climate Change 2007: The Physical Science Basis," Cambridge University Press, Cambridge, 2013.

[3] N. S. M. Safaii, Z. Z. Noor, H. Hashim, Z. Ujang and J. Talib, "Projection of $\mathrm{CO}_{2}$ Emissions in Malaysia," Environmental Progress and Sustainable Energy, Vol. 30, No. 4, 2011, pp. 658-665. http://dx.doi.org/10.1002/ep.10512

[4] SIE-Cameroon, "Situation Energétique du Cameroun: Rapport 2011," Ministère de L'eau et de L'énergie, Yaoundé, 2012.

[5] J. G. Tamba, D. Njomo and E. Tonye-Mbog, “Assessment of $\mathrm{CO}_{2}$ Emissions in the Petroleum Refining in Cameroon," Universal Journal of Environmental Research and Technology, Vol. 1, No. 4, 2011, pp. 455-466.

[6] J. G. Tamba, D. Njomo, J. L. Nsouandele, B. Bonoma and S. Bogning, "Assessment of Greenhouse Gas Emissions in Cameroon's Road Transport Sector," Universal Journal of Environmental Research and Technology, Vol. 2, No. 5, 2012, pp. 475-488.

[7] AES-Sonel, "Rapport D'activité 2011,” AES-Sonel, 2012.

[8] DPDC, "Manuel D'utilisation de la Centrale," Wartsila, 2008.

[9] INS, "Annuaire Statistique du Cameroun," Institut National de la Statistique, Paris, 2011.

[10] DPDC, "Rapport D'activité 2012," Dibamba Power Development Company, Dibamba, 2013.

[11] G. Villalba and E. D. Gemechu, "Estimating GHG of Marine Port-The Case of Barcelona," Energy Policy,
Vol. 39, No. 3, 2011, pp. 1363-1368.

http://dx.doi.org/10.1016/j.enpol.2010.12.008

[12] J. N. Blignaut, M. R. Chitiga-Mabugu and R. M. Mabugu, "Constructing a Greenhouse Gas Emissions Inventory Using Energy Balances: The Case of South Africa for 1998," Journal of Energy in Southern Africa, Vol. 16, No. 3, 2005, pp. 21-32.

[13] M. Zhang, X. Liu, W. Wang and M. Zhou, "Decomposition Analysis of $\mathrm{CO}_{2}$ Emissions from Electricity Generation in China," Energy Policy, Vol. 52, 2013, pp. 159-165. http://dx.doi.org/10.1016/j.enpol.2012.10.013

[14] R. Shabbir and S. S. Ahmed, "Monitoring Urban Transport Air Pollution and Energy Demand in Rawalpindi and Islamabad Using Leap Model," Energy, Vol. 35, No. 5, 2010, pp. 2323-2332. http://dx.doi.org/10.1016/j.energy.2010.02.025

[15] Unit-Juggler, "Convertisseur Simple-Flexible et Gratuit", 2013.

http://www.unitjuggler.com/convertir-energy-de-GcmNG -en-GJ.html

[16] IPCC, "2006 IPCC Guidelines for National Greenhouse Gas Emissions," 2006. http://www.ipcc-nggip.iges.or.jp/public/2006gl/vol2.html

[17] C. Y. Chung and P. L. Chung, “Assessment of Carbon Dioxide Reduction Efficiency Using the Regional Carbon Neutral Model-A Case Study in University Campus Taiwan," Low Carbon Economy, Vol. 2, No. 3, 2011, pp. 159-164. http://dx.doi.org/10.4236/lce.2011.23020

[18] IPCC, "Revised 1996 IPCC Guidelines for National Greenhouse Gas Inventories," 1996. http://www.ipcc-nggip.iges.or.jp/public/gl/invs6.html 